\title{
Participatory approach to conservation and management of protected areas in Nigeria: Case study of Osse River Park Project
}

\author{
Sunday Oladipo Oladeji and Damilola Fatukasi \\ Department of Ecotourism and Wildlife Management, Federal University of Technology, Akure, Nigeria.
}

Received 15 April, 2014; Accepted 8 July, 2015

\begin{abstract}
Stakeholder involvement and participation are essential in achieving sustainable integration and sound environmental management of protected areas in Nigeria. Involvement and participation of local communities in conservation and management of Osse River Park were assessed through administration of structured questionnaires while relevant State Government Ministries in Environmental and Nature Resources Management and Non-Governmental Organizations (NGOs) were interviewed to complement the study. Although the local communities were observed to be involved at the inception of the Park, their participation in park management is presently low (25\%). Accordingly, $70 \%$ of the respondent claimed that the government and NGOs invested more in environmental education, park protection and surveillance than in meeting socio-economic needs of the people. Small proportion of the respondents identified distribution of plant seedlings $(20 \%)$ and intensification of conservation education $(10 \%)$ as an urgent need. This result suggests the need to increase financing from the present 5 to $25 \%$ NGO's input in fund raising and the government's commitment in finance. The study identified improving stakeholders' relations, capacity building, and integrating communitybased natural resource management as important. It was recommended that the ministries and NGOs engaged in environmental and biodiversity conservation which direct more efforts toward the development of sustainable practices that facilitate stakeholders' participation in the integration process.
\end{abstract}

Key words: Capacity building, conservation education, stakeholder's involvement and participation, sustainable development.

\section{INTRODUCTION}

A protected area is an area of land and/or sea especially dedicated to the protection and maintenance of biological diversity, and of natural and associated cultural resources and managed through legal or other effective means

*Corresponding author. E-mail: sooladeji@futa.edu.ng or oladejisunny@yahoo.com. Tel: +231888517228 or +23480698896. 
(International Union for Conservation of Nature/World Conservation Monitoring Centre (IUCN/WCMC), 1994). According to Dudley (2008), all protected areas should aim to conserve the composition, structure, function and evolutionary potential of biodiversity. Based on management objectives, the International Union for Conservation of Nature and Natural Resources (IUCN) recognizes six categories of protected areas (Phillips, 2002).

National Parks are classified as protected areas managed for ecosystem conservation and recreation. They fall under Category II of protected areas with clear boundaries drawn sufficiently to contain one or more entire ecosystem which are not subject to material modification by human exploitation or occupation (IUCN/WCMC, 1994). National Parks are therefore considered as gene pool of immeasurable biodiversity.

Biological diversity (or biodiversity) includes all the different plants, animals and microorganisms, the genes they contain and the ecosystems of which they form a part (National Environmental Awareness Campaign (NEAC), 2012). The Royal Society (2003) asserts that our dependence on biodiversity is absolute and 'without it, humans would not be able to survive'. Ecosystem services were derived from biodiversity including domesticated or wild species for food, fibres, fuel, pharmaceuticals and many other purposes. In addition, added value was derived from the influence of biodiversity on climate regulation, water purification, soil formation, flood prevention and nutrient cycling, etc. The impact of biodiversity on our culture and its aesthetic value are also immense (Daily, 1997; Balmford et al., 2002). Biodiversity is thus fundamental for meeting current and future social, cultural, ecological and economic livelihoods demands of the communities and it is an essential component of sustainable development. Thus, any attempt to restrict human from unsustainable exploitation of natural resources tend to receive precarious resistance. Rather than enforcing law, arrest and prosecuting the locals that are custodian of these resources, there is need to develop techniques that will ensure that their needs are integrated.

In many cases, traditional approaches to park management through law enforcement have been unable to balance the competitive objectives of conserving biodiversity (Wells and Brandon, 1992). Hence, integrated approaches have evolved to facilitate interaction and participation of the relevant stakeholders in park management. Integrated Natural Resource Management (INMR) is a holistic and multidisplinary approach that provides opportunity for interaction and involvement of relevant stakeholders. IUCN recognizes INMR approach as a way to establish and manage protected area and make substantive contributions to conservation strategy, if only the skill in selecting, combining and processing INMP approach is developed (Dudley, 2008). World Bank
(1990), launched Integrated Conservation and Development Projects (ICDPs) as a key initiative aimed at meeting the increasing demands on biodiversity resources (Wells et al., 1992). With ICDPs in place, the numerous challenges facing biodiversity resources are hoped to be receiving necessary attentions.

Proper selection, combination and processing of Integrated Natural Resource Management approach with other similar community based practices like Community Based Ecotourism Practice will provide opportunity for achieving sustainable development whereby social, cultural and economic needs of the communities' vis-àvis biodiversity conservation objectives are met (Oladeji, 2015). As part of the aim of the guidelines prepared by the general assembly of International Council for Monuments and Sites (ICOMOS) at its tenth session in 1993; it was noted that sustainable management strategies for change which respect cultural heritage require the integration of conservation attitudes with contemporary economic and social goals including tourism (ICOMOS, 1993). According to UNDP (2004), Community Management of Protected Areas Conservation (COMPACT) is a demonstration project within the context of Integrated Conservation and Development Projects (ICDPs) born out of the need to redress the imbalance between natural resources conservation and the local community's needs. In view of the peculiarity of this project targeted at promoting visit to the park as a means of generating revenue, ensure conservation of the rich biodiversity resources of the park, and improving the social and economic lives of the host communities, ecotourism should be given attention. Ecotourism is considered as an environmentally responsible and sustainable form of visit to nature based site in order to appreciate nature in its pristine and other accompanied cultural features. Ecotourism tends to minimize negative impact on the ecosystem while optimizing contribution to conservation and improvement of socioeconomic benefit to the local communities. Ecotourism has been embraced over the years as an ideal mechanism for attaining both the economic and ecological sustainability. It has brought the promise of achieving conservation goals, improving the well-being of local communities and generating new business promising a rare win-win-win situation (Drumm and Moore, 2002). Ecotourism improves understanding, facilitate participation, and involvement among the stakeholders. Ecotourism industry creates synergy between conservation and social-economic needs of the local communities.

Research interest in understating stakeholders' participation and involvement in the management of protected areas has been increasing in recent times. This is a serious consideration for this work hinged on the need to devise strategies for effective management and conservation of rich biodiversity resources in Osse River Park, with attendants increasing anthropogenic activities 
such as clear felling, encroachment, unsustainable harvest and other social-ecological crisis emanating across protected areas as reported in literatures (Swarthout and Steidl, 2001; Oladeji et al., 2012; Johnson et al., 2005). Another reason for increasing interest in stakeholder's participation and involvement is that managers of natural resources are facing challenges in designing a conceptual framework targeted at sustainable management of biodiversity resources in such a way that negative ecological impact is minimized and improve livelihood and economic well-being of the local in the developing countries especially those that are leaving adjacent to protected areas are guaranteed.

Stakeholders may include a variety of people, from members of government and industry to indigenous and international non-governmental organizations (NGOs), and may engage in diverse activities to make a living, thereby using resources in a multiplicity of ways. NGOs as part of stakeholders in conservation and management of protected areas played significant roles in sensitizing the community, in conflict resolution and in provision of funds and in training as reported in Georgian-Abkhazian, Southern Russia and South Western Nigeria (Stewart, 2004; Oladeji and Afolayan, 2009). Stewart (2004) emphasized that the advantages of NGOs in conflict prevention are that they 'do not carry the baggage of government statuses, are closer to and better informed about developments within the community, are 'often made up of people of stature within communities' and promote functional concerns and therefore can transcend ethnic boundaries.

Local communities are another relevant stakeholder that is largely recognized by conservationists and development practitioners in view of the crucial roles being play in the management of natural resources and habitats and many have adopted 'if it pays it stays' principle (Rosario, 1997). The United Nation Conference on Environment and Development (UNED) (1992) stressed that policy development and implementation on biodiversity should take place in cooperation with all interested parties, especially the private sector and local and indigenous communities. The emphasis is on recognizing local communities adjoining protected areas as the key stakeholder in decision making and management as a way to ensure their cooperation and involvement in biodiversity conservation. According to Skidmore et al. (2006), the local community should not be forced, but rather be given opportunity to participate and involve in projects which affect their lives. Such an approach upheld the basic rights and a fundamental principle of democracy. Organizing the people into groups facilitate group discussions, dialogue and equal participation of the stakeholders. MacDonald and Service (2007) hold that the task of designing modern, crosscutting, transparent, evidence-based interdisciplinary decision making is not only conceptually challenging, but also necessitates a huge increase in local capacity for democracy and decision making.

The main actor in traditional management of natural resources is the Government. Government exists at the Local, State, National and Global levels; their level of involvement in conservation and management of park resources can therefore not be ignored. In contrast to the "traditional paradigm", in which protected areas were managed by the central government, a "new paradigm" emphasis cooperation in the governance of protected area. For instance, Federal Government of Nigeria through National Park Service, Federal Ministry of Environment and Natural Resources oversee management of National Parks with minimal or without external input. Another challenge of traditional management of protected area is that it is being dominated by natural scientists, thereby failed to address the social, economic and political needs of the community. The new paradigm as being proposed in this study will ensure sustainable management through cooperation, participation and involvement of relevant stakeholders; it will serve as blueprint for sustainable park management in Nigeria and other countries where traditional approach to park management is yet to be abolished. Phillips (2003) reported that traditional management of protected areas dominated by natural scientists is gradually being replaced by socio political processes requiring consultations, sensitivity, and astute judgment.

Osse River Park formerly known as Ifon Game reserve is presently undergoing reformation and transformation aimed at enlisting it as one of the National Parks in Nigeria. One major challenge that protected areas in Nigeria is having is in the area of transformation from game reserve to National Park. Ifon Game reserve was under the management of Ondo State Government under direct statutory supervision and management of the Department of Wildlife, Ministry of Natural Resource, Ondo-State, while the Ministry of Environment, Department of Natural resources plays the backup role. Presently, NGO such as Nigerian Conservation Foundation (NCF) with other registered NGO in the state such as Nigerian Environmental Conservation Organization (NECOR) and Nigerian Environmental Study Team (NEST) are considered to be playing complementary roles in the efforts to transform the game reserve and ensuring its enlistment as one of the national parks in Nigeria. Unique fauna and flora resources in the game reserve as well as the rich diverse cultural values of the host communities have been assessed and documented (Agbelusi and Afolayan, 1991; NCF, 2007). The present management technique is being considered as a traditional approach to natural resource management and it is not sustainable to achieve the set objectives. There is therefore a need for a change of paradigms from topdown to a holistic and participatory approach. Integrated natural resource management approach will go a long 


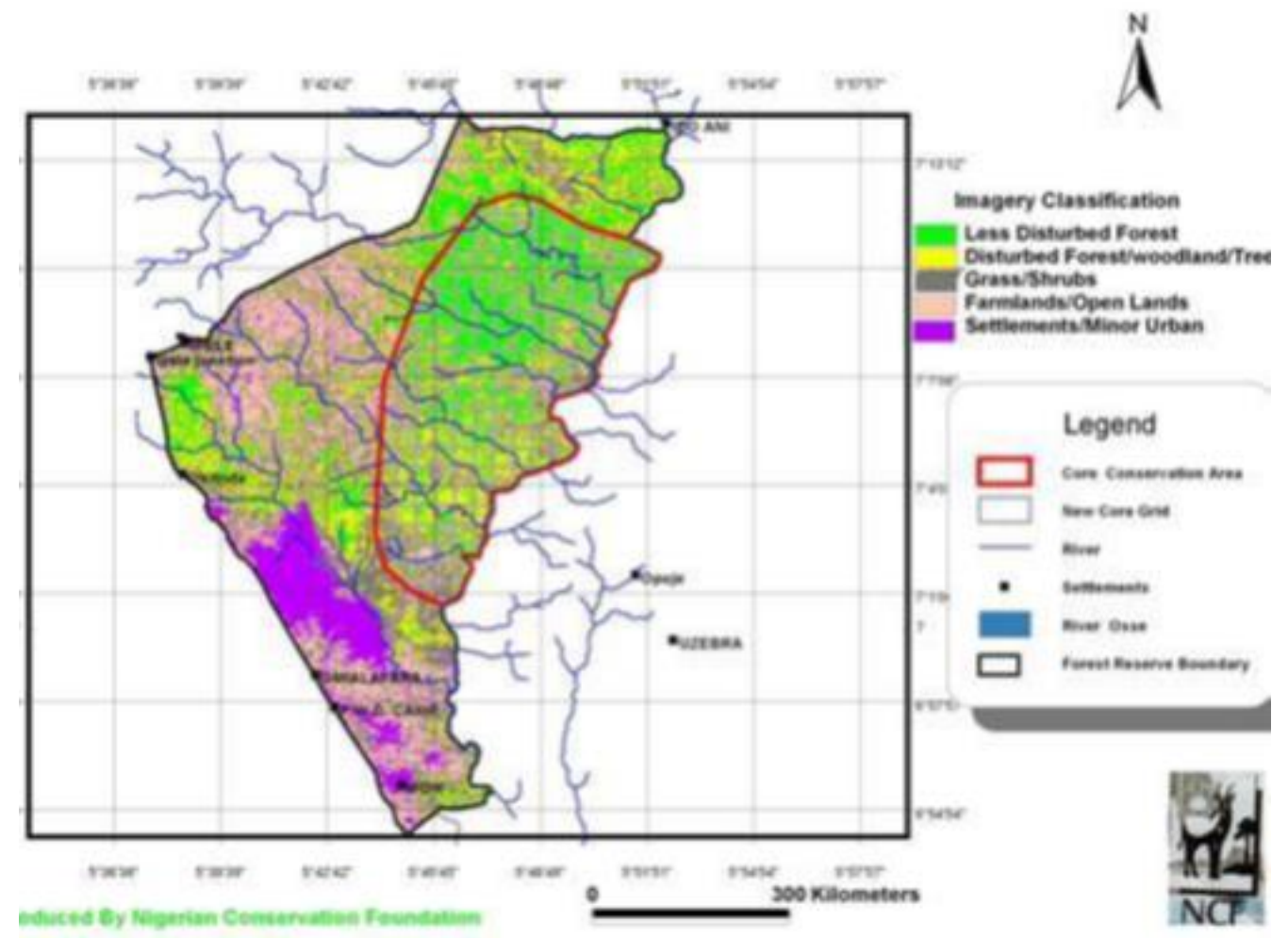

Figure 1. Map of Osse River Park.

way in addressing the identified imbalance among the stakeholders. This strategy will facilitate sustainable conservation and management of the park through proper participation and involvement of all the stakeholders. It is recommended that government established ministries/organizations and environmental NGO's increased focus on research in biodiversity conservation and development of community based practices in the integration process. Simpson (2001) holds that the sustainable approach to planning is based on the achievement of two prerequisites: a strategic and longterm orientation in planning and multiple stakeholder participation in the planning process. The local communities, the government and NGOs should consider their roles and ensue that these are properly integrated in the planning process in order to achieve the aim of conserving the biodiversity in the park.

\section{METHODOLOGY}

\section{Study area}

Osse River Park is located in Osse Local Government area of Ondo State, Nigeria. The park covers a total area of $282.72 \mathrm{~km}^{2}$ which is equivalent to $8.4 \%$ of Ondo State. It is situated between $6^{\circ} 40^{\prime} \mathrm{N}$ and $7^{\circ} 5{ }^{\prime} \mathrm{N}$ and $5^{\circ} 4{ }^{\prime} 3^{\prime \prime} \mathrm{E}$ and $5^{\circ} 55^{\prime} \mathrm{E}$. It is bounded in the west and south by the Akure Benin express road, on the north west by Ipele-
Ido-ani express way and on the east by river Osse and Asaboro rubber plantation (NCF, 2007). Osse River Park has a unique ecosystem diversity because of its high forest vegetation as well as Savanna. The three major vegetation types in the park include tropical rainforest area covering $50 \%\left(150.22 \mathrm{~km}^{2}\right)$, savanna woodland including forest/savanna mosaic which covers an area of $132.48 \mathrm{~km}^{2}$ and the riverine forest which occurs along the courses of the major rivers draining the reserve (Figure 1). In view of its location, it is easily accessible from all sides by visitors coming from the Southern and Northern part of Nigeria. It is about $20 \mathrm{~km}$ from Owo, $80 \mathrm{~km}$ from Akure, $6 \mathrm{~km}$ from Ifon and about $80 \mathrm{~km}$ from Benin City. The reserve is drained by five important rivers which include Big Osse, little Osse and river Uwese, Okua and Orokin. Osse River Park is surrounded by various communities including towns, villages, settlement and camps among which are: Ifon, Igbonla, Ikaro, Uwesse camp, Omi-arafa, Ori-ohi camp, Ipele, Igbogburu (Ido-ani), Ago-Igbira, Ago-Alao, Ofale and Elegbeka. While Ipele is under Owo Local Government Area, other communities fall under Osse Local Government Area. None of these communities is situated within the park protected area. According to Federal Republic of Nigeria Official Gazette (FRNOG, 2009), the population of Ose Local Government Area was put at 144,139 with male constituting the highest percentage of $50.73 \%$. However, this official gazette lacks breakdown of the figure for each of the selected communities unlike the National Population Commission Census Final results for 1991 .

\section{Methods of data collection}

Qualitative and quantitative methods of social survey were adopted 
Table 1. Location of the respondents.

\begin{tabular}{lcc}
\hline Location & Frequency & Percentage \\
\hline Elegbeka & 88 & 22.6 \\
Ifon & 116 & 29.7 \\
Idoani & 84 & 21.5 \\
Ipele & 102 & 26.2 \\
Total & 390 & 100 \\
\hline
\end{tabular}

in this research work. The administered questionnaire to the host communities was designed and structured to include questions on the demographic characteristics of the respondents; level of awareness on biodiversity conservation education; method of awareness; involvement in identified biodiversity conservation activities; areas of involvement in park management and suggestion for improve participation and involvement. Although two major sources of information on biodiversity conservation education were identified to include media and community sensitization programs, however level of awareness on biodiversity education was measured as either high or low based on (1) the frequency of hearing the jingles through media or number of attendance at the community sensitization programs and (2) number of sources of information. Respondents that signified that they have listened to jingles on radio or television not less than ten times within a year were rated high. Also rated high, are those that signified that they have attended organized community sensitization programs for at least three times within a year. All the respondents that indicated otherwise were rated low. Respondents were asked to indicate any or both of the biodiversity conservation related activities identified to be practicing. They were also given option to indicate if neither. The two identified biodiversity conservation related activities were planting of trees to serve as fence, shade, edible fruit and other economic advantages; and domestication of grasscutter and snail. Areas of involvement in park management activities are divided into involvement in park surveillance/protection and serving as member of community advocacy group. Community advocacy group consist of people that facilitate discussion between the government and the community, for instance, whenever community sensitization programmes are to be organized, they are those that plan on modalities to execute this act. Park surveillance members are members of the community employed as uniform men by the government to assist in monitoring the park.

The structured questionnaire was self-administered among the four neighbouring communities. The names of these communities were Elegbeka, Ifon and Ido-ani in Ose Local Government Area and Ipele in Owo Local Government Area. Local Government Areas were selected through a multi-stage approach. In the first stage adjoining communities were purposively selected based on their proximity to the park (Sarantakos, 1988; Bamgboye and Okoruwa, 2009) with consideration of the potential for the locals to engage in anthropogenic activities that have direct impacts on the forest resources (Oladeji et al., 2012) (Table 1). In the second stage, the communities were stratified into streets and quarters while in the third and the last stage, the respondents were randomly selected. A total of three hundred and ninety (390) respondents at house levels were randomly selected across the named streets and quarters in each community (Dohrmann et al., 2006; Kennel and Liu, 2011). Fifteen key informants considered to be knowledgeable about the social and economic livelihood of the people haven stayed in these communities for over 20 years were selected for interaction in each community making a total of 60 key informants in all. Interview guide was prepared to facilitate conversation with the government and NGO. It contains guided questions such as level and areas of involvement in biodiversity conservation and park management and percentage of financial contribution.

\section{Interview}

In order to complement this research findings, oral interview were held with the staff $(n=20)$ of the two relevant Government Ministries and with a staff of Nigerian Conservation Foundation (NCF). Ten respondents were purposely selected in each department in the two relevant ministries. The staff from these two departments were purposively selected based on the fact that they represent government on issues pertaining to conservation and management of the park. The two government ministries are the Ministry of Agriculture and Ministry of Environment and Departments of Wildlife and Department of Natural Resources, respectively. These ministries via the affiliated departments are saddle with the responsibilities to oversee Biodiversity Conservation and Environmental Management in Ondo-State. A formal interview was conducted for the project monitoring officer of NCF assigned to Osse River Park Project. He was purposely assigned by NCF as the representative of the organization as at the time of conducting this research work. He was the only staff from NCF that the researchers were directed to meet in order to collect relevant information on the efforts and contributions of NCF to Osse River Project. Other NGO like Nigerian Environmental Conservation Organisation (NECOR) was reported to register with Ondo State Ministry of Environment and participate actively in conservation education in adjoining communities. The researchers were directed to meet members of this organization to collaborate their findings.

\section{Data analysis}

The collected data were analyzed both qualitatively and quantitatively. Data collected through the administered questionnaire was analyzed quantitatively using Statistical Packages for Social scientist (SPSS) version 20 and presented in tables. Information obtained on the interview held with the key informants and NGOs was analyzed qualitatively.

\section{RESULTS}

\section{Demographic information of the respondents}

Of the total number of persons interviewed, $56.3 \%$ were male and $43.7 \%$ were female, $>20$ years were $10.2 \%$, $31.5 \%$ were between 30 and 40 years, $>50$ were $11.4 \%$ 
Table 2. Social and demographic characteristics of the respondents.

\begin{tabular}{|c|c|c|}
\hline Age & Frequency & Percentage \\
\hline$>20$ & 40 & 10.2 \\
\hline $21-30$ & 115 & 29.5 \\
\hline $31-40$ & 123 & 31.5 \\
\hline $41-50$ & 68 & 17.4 \\
\hline$>50$ & 44 & 11.4 \\
\hline \multicolumn{3}{|l|}{ Educational background } \\
\hline Primary & 112 & 28.7 \\
\hline Secondary & 186 & 47.7 \\
\hline Tertiary & 68 & 17.4 \\
\hline No formal education & 24 & 6.2 \\
\hline \multicolumn{3}{|l|}{ Occupation } \\
\hline Farming & 215 & 55 \\
\hline Trading (in non-forest/agricultural items and agricultural produce) & 101 & 26 \\
\hline Artisan & 51 & 13 \\
\hline Civil servant & 23 & 6 \\
\hline \multicolumn{3}{|l|}{ Period of stay } \\
\hline $1-10$ & 110 & 28 \\
\hline $11-20$ & 101 & 26 \\
\hline $21-30$ & 55 & 14 \\
\hline $31-40$ & 56 & 15 \\
\hline $41-50$ & 48 & 12 \\
\hline$>50$ & 20 & 5 \\
\hline Total & 390 & 100 \\
\hline
\end{tabular}

(Table 2). A small number (6.2\%) had no formal education. Subsistence farming was the most common form of occupation (55\%), followed by sales of nonagricultural and agricultural produce (26\%) and artisans $(13 \%)$. Analysis of result obtained on the period of stay in the community revealed that large percentage of the respondents has spent over 30 years in these communities.

\section{Knowledge and participation in biodiversity conservation}

Greater percentage of the respondents (62\%) indicated that their level of awareness on biodiversity conservation was high (Table 3 ). This can also be affirmed through the various means by which these $(62 \%)$ respondents indicated that they got the awareness. For instance large percentage of the respondents $(77 \%)$ claimed that they were aware of biodiversity conservation education through repeated jingles of not less than ten times within a year on media (radio and television) on the danger of bush burning, indiscriminate killing of wild animals and the need to promote domestication of plants and animals. Respondents that expressed their level of awareness based on the fact that they have attended sensitization meetings or programmes (such as World Environment Day, Tree Planting Day and International Day of Biodiversity) organized in the community on the need to desist from activities such as bush burning especially during the dry season period to avoid inferno and uncontrolled killing of wild animals were considerably low $(16 \%)$ (Table 4). However, despite the high level of awareness on biodiversity conservation education in the study area, relatively low percentage $(36 \%)$ of the respondents are engaging in tree planting and wild animal domestication for social and economic purposes. Others $(64 \%)$ indicated that they did not engage in any of these acts considered as biodiversity conservation activities. Tree planting exercise was rated the highest as a regular practice $(23 \%)$ followed by domestication of wild animals such as rearing of grasscutter/giant rat and snail (13\%) (Table 5). Species of trees that are being planted because of their social and economic importance includes 
Table 3. Awareness on conservation.

\begin{tabular}{lcc}
\hline Awareness on conservation & Frequency & Percentage \\
\hline High & 242 & 62 \\
Low & 148 & 38 \\
Total & 390 & 100 \\
\hline
\end{tabular}

Table 4. Medium of awareness.

\begin{tabular}{lcc}
\hline Medium of awareness & Frequency & Percentage \\
\hline Media & 301 & 77 \\
Community/Sensitization & 62 & 16 \\
No respond & 27 & 7 \\
Total & 390 & 100 \\
\hline
\end{tabular}

Table 5. Biodiversity conservation activities.

\begin{tabular}{lcc}
\hline Efforts & Frequency & Percentage \\
\hline Tree planting Tectona grandis, Nauclea diderrichi, Khaya spp., and Gmelina arborea & 90 & 23 \\
Wild animal domestication e.g grasscutter domestication and snailry & 50 & 13 \\
Not engaging in conservation acts & 250 & 64 \\
Total & 390 & 100 \\
\hline
\end{tabular}

Table 6. Involvement in park management activities.

\begin{tabular}{lcc}
\hline Involvement & Frequency & Percentage \\
\hline Involve & 35 & 9 \\
Not involve & 250 & 64 \\
No response & 105 & 27 \\
Total & 390 & 100 \\
\hline
\end{tabular}

Table 7. Areas of involvement in park management activities.

\begin{tabular}{lcc}
\hline Areas of involvement & Frequency & Percentage \\
\hline Park surveillance/protection & 19 & 54 \\
Community advocacy/informant & 16 & 46 \\
Total & 35 & 100 \\
\hline
\end{tabular}

Teak Tectona grandis, Nauclea diderrichi, Khaya species, and Gmelina arborea (Table 5). Relatively low percentage of the respondents $(9 \%)$ indicated that they involve in park management activities (park surveillance/protection and community advocacy group); those that did not involve represent the highest percentage (64\%) while others $(27 \%)$ did not respond (Table 6$)$. The areas of involvement as indicated by the respondents include park surveillance/protection (54\%) and community advocacy group (46\%) (Table 7). Result of the interview held with the local key informants was used to complement information obtained through administration of questionnaire on the traditional occupation of the respondents to include trading in sales of bush meat, hunting, fishing, 
Table 8. Suggestions for improve biodiversity conservation and communities participation.

\begin{tabular}{lcc}
\hline Suggestion & Frequency & Percentage \\
\hline Creating employment & 125 & 32 \\
Capacity building training & 117 & 30 \\
Provision of inputs & 78 & 20 \\
Intensive conservation education & 39 & 10 \\
Change in management approach & 31 & 8 \\
Total & 390 & 100 \\
\hline
\end{tabular}

Table 9. Level of involvement, areas of involvement and percentage of financial contributions to biodiversity conservation.

\begin{tabular}{lcccc}
\hline \multirow{2}{*}{$\begin{array}{l}\text { Level of involvement in biodiversity conservation } \\
\text { Fully involved }\end{array}$} & $\begin{array}{c}\text { Ministry of Agriculture } \\
\text { Department of Wildife }\end{array}$ & $\begin{array}{c}\text { Ministry of Environment } \\
\text { Department of Natural Resources }\end{array}$ \\
\cline { 2 - 5 } & Frequency & Percentage & Frequency & Percentage \\
\hline Moderately involved & 9 & 90 & - & - \\
Partially involved & - & - & 2 & 20 \\
& 1 & 10 & 8 & 80 \\
Areas of involvement in biodiversity conservation & & & & 50 \\
Environmental Education and awareness & 5 & 50 & 5 & 10 \\
Finance & 1 & 10 & 1 & 10 \\
Advocacy & 1 & 10 & 1 & 20 \\
Provision of input/research & 2 & 20 & 2 & 0 \\
Protection and Surveillance & 1 & 10 & 0 & 10 \\
No response & 0 & 0 & 1 & 0 \\
Percentage of financial commitment & & & & 10 \\
$10 \%$ & - & 0 & - & 0 \\
$25 \%$ & 2 & 20 & 1 & 90 \\
$50 \%$ & - & 0 & - & 100 \\
No response & 8 & 80 & 9 & \\
Total & 10 & 100 & 10 & \\
\hline
\end{tabular}

honey tapping, produce marketing and gathering of forest fruit or seed for sales. Fruits/seeds from species of trees such as Arvingia gabonensis, Bligha sapida and Parkia biglobosa are collected in the forest for sales as a mean of livelihood. The informants indicated that the categories of people involve in these activities were not constituted into group. Thus meeting them to discuss on their mode of activities in the course of carrying out this study was difficult. Suggestions for improve biodiversity conservation and increase communities' participation in the management of the park were rated in order of priority to include creating employment/job opportunities for the people $(32 \%)$, provision of capacity building training/financial empowerment for the locals to start their small scale businesses $(30 \%)$, and change in the management approach to conservation (8\%) (Table 8).
Only 20 and $10 \%$ of the respondents identified provision of inputs such as tree seedlings, boot, and uniform for those in park surveillance and intensification of conservation education through media and community sensitization as needing attention, respectively.

\section{Result of the analysis of interview held with the government agencies}

Result of the analysis of interview held with the staff of the Ministry of Agriculture and Staff of the Ministry of Environment is revealing (Table 9). The result shows that the Ministry of Agriculture is involved in creation of environmental education (50\%), protection and surveillance $(10 \%)$, distribution of inputs such as tree 
seedlings (20\%), advocacy (10\%) and finance (10\%). Based on the responses received from the staff, the level of financial commitment of the ministry is put at $25 \%$ level. The level of involvement of the people in the four adjoining local communities on biodiversity conservation activities and park management at the inception was considered to be high (75\%) unlike at present which is very low (25\%). This explains the reason for attendant increasing rate of anthropogenic activities threatening biodiversity resources being conserved in the park while relatively few of the people engage in community advocacy meetings (46\%) (Table 7 ). The list of anthropogenic activities as being kept by the ministry include illegal lumbering activities, forest fragmentation/land clearing for farming and cultivation of marijuana hemp, hunting and poaching.

In the Ministry of Environment, their areas of involvement in biodiversity conservation included environmental education (50\%), provision of input such as seedlings (20\%), finance (10\%), and advocacy $(10 \%)$, while $10 \%$ did not respond. The level of financial contribution of the ministry among the $10 \%$ that indicated financing as an area of involvement of the ministry in the park was $25 \%$, while others did not respond to this question.

\section{Result of the analysis of interview held with the staff of NGO}

Oral formal interview was conducted for the staff of NCF (Environmental NGO) as the organization designate or representative assigned to monitor Osse River Park Project. Result of the quantitative analysis of the interview is revealing. This was complemented by information received from members of NECOR (a community based NGO registered with Ondo State Government). While NECOR involved in community sensitization programmes like celebration of World Environment Day, International Day for Biodiversity and Tree planting Day, NCF on the other hand involved in various capacities as rated thus provision of environmental education, community sensitization and public awareness (45-50\%), stakeholders' relation, engagement, integration (25\%), funds raising (5-10\%) and protection and surveillance (25-30\%). Involvement and participation of the host communities in conservation and management of the park was considered to be very low at present $(20 \%)$. Factors responsible for low participation and involvement of the host communities are ranked in order of priority to include lack of financial assistance/empowerment to improve the livelihood of the host communities to Osse River Park (25\%), failure of the government to constitute an independent management unit to run the affairs of the park (13\%), absence of external funding from international and local donors
(13\%), wrong government approach to the management of the park (top down approach rather than bottom top approach) (13\%), lack of intensive conservation education (13\%), nonexistence of legislation rules from the state House of Assembly to guide in the management of the park $(9 \%)$, unavailability of management plan for the park $(7 \%)$ and improper integration of the host communities in the planning, implementation and evaluation of the park $(7 \%)$. In order to ascertain authenticity of the result obtained from the interview held with the staff of NCF consent of the organization was sought after with a promise that copy of this research will be made available.

\section{DISCUSSION}

\section{Demographic characteristic of respondents and implication on biodiversity conservation}

Greater percentage of respondents are male (56.3\%), this support the findings of Federal Republic of Nigeria Official Gazette (FRNOG, 2009), that reported the population of Ose Local Government Area as 144,139 with male constituting the highest percentage of $50.73 \%$. Findings from literatures revealed that to conserve biodiversity, there is need to understand and expose gender-differentiated biodiversity practices, gendered knowledge acquisition and usage (United Nation Millennium Goal, 2008; European Union (EU), 2015). The authors opined that projects integrating gender dimensions generate superior results. Gender considerations are not solely a women's issue, it transcend all other demographic characteristics in a society; and this outlook could yield advantages for whole communities and benefit both sexes. In depth understanding of occupational characteristics of the people surrounding the proposed park will assist the management on the type of projects that will be designed to meet their social economic needs. Since larger percentage $(55 \%)$ of the respondents engaged in subsistence farming, it is expedient to promote and encourage sustainable farming practices among the people in the host communities. Rather than embarking on arrest and enforcement of people to vacate the encroached area of the park the people can be trained on modern techniques of farming supported with agricultural inputs such as improved or hybrid crops and government should introduce sustainable land use practice in the buffer zone area of the park. Practice of agroforestry system provides a different land use option, compared with traditional arable and forestry systems since it allows cultivation of trees and agricultural crops in intimate combination with one another either in temporal or spatial arrangement (Kabwe et al., 2009). Agroforestry system such as taungya farming can be promoted as a 
sustainable land use practice that allows farmers to cultivate perennial crops such as banana/plantain either in spatial or temporal sequence with the trees. Agroforestry makes use of the complementarily between trees and crops, so that the available resources can be more effectively exploited. It is a practice that respects the environment and has both ecological and economic advantage. Buffer zone of the park can support practice of agroforestry system whereby arable crops can be cultivated to meet the social and economic needs of the people. Another advantage of agroforestry is that it allows subsistence as well as commercial farming. This forms part of the basis for the formulation of buffer zone initiative across protected areas in some Asia countries like Nepal and Bangladesh (Sharma and Yonzon, 2005; Sharma et al., 2005). A buffer zone is a designated area surrounding a protected area within which the use of forests by local communities is allowed in order to support their gainful efforts in biodiversity conservation. It is aimed at minimizing adverse human impacts on protected areas by meeting livelihoods needs of local communities without interference with the core zone. Encroachment and all other form of anthropogenic activities being experienced in Ose River Park is not peculiar to this area alone, it is a global problem facing protected areas. As a response to declining land productivity, farmers open up forests to expand to new areas and this has led to loss of extensive forests and subsequent land degradation (Kabwe et al., 2009). According to Spears et al. (1994), natural forests throughout the developing world have been depleted and degraded, local populations have increasingly turned to remnant patches of open woodlands, forest fallows and other farming systems for supplying their essential forest product needs and for inputs required in maintaining agricultural productivity. Conceptual framework to guide efforts at increasing crop production, involving the local communities in conservation and at the same time reducing environmental consequence of agriculture practice is the antidote. FAO (2013) emphasized that millions of people could escape poverty, hunger and environmental degradation if countries put more effort into promoting agroforestry, an integrated approach combining trees with crops or livestock production benefits. Other demographic characteristics of the host communities that should be considered for sustainable development of the area to be achieved include the level of education of the people. Since a small number $(6.2 \%)$ of the population had no formal education, exposing them to training on modern and mechanized view of forest conservation and management will not be difficult. Training and workshop to improve their skill in small scale enterprise such as handling, domestication and management of wild animals and indigenous plants, apiculture, mechanized farming, tour operators, park interpreters, caterers and waiters should be provided as means of generating employment for the teeming population of the youth representing 29.5 to $31.5 \%$ of the population. Adeyemo and Oladeji (2013) opined the high literate level in a community as is an impetus for other sustainable practice like ecotourism to thrive.

\section{Stakeholders' participation and involvement in biodiversity conservation}

International best practice scenarios have shown that tripartite partnership involving government, the private sector, and local communities work best in conserving biodiversity (Spenceley, 2003). It was observed that despite high level of awareness being created by the Government and NGOs on biodiversity conservation education (62\%) and inputs in form of tree seedlings $(20 \%)$ relatively low percentage of the respondents $(36 \%)$ engaged in biodiversity ex-situ conservation practices like tree planting $(23 \%)$ and domestication of wild animals $(13 \%)$. The percentage of those participating in park management was equally relatively low $(9 \%)$. While large percentage of the respondents (64\%) indicated that they did not engage in any biodiversity conservation practices. This calls for serious consideration especially if the objectives of the park and ongoing reformation and transformation aimed at enlisting area as a park are to be realized. In as much as development of ecotourism practice is part of the objectives of establishing the park, there is need to encourage conservation of its rich ecotourism potentials. Development of the rich ecotourism resources in the park will contribute immensely to the social and economic livelihood of the surrounding communities (Oladeji and Kayode, 2013). Local stakeholders' participation has been identified as a vehicle through which successful ecotourism can be achieved (Epler, 2002). Efforts of the government and NGO in sensitizing the community on the need to engage in biodiversity conservation notwithstanding the resultant effect of this act should be reflected in attitudinal changes among the locals on the value attached to biodiversity resources within their reach, hence their contributions cannot be ignored in the integration process. Apart from tree planting and domestication of few species of animals which are ex-situ conservation practices, other sustainable in-situ conservation practices like construction of park structures for recreation and relaxation, establishment of nursery care for shrubs or trees, habitat restoration, large-scale adoption of renewable energy technologies should be inculcated in these communities. This calls for orientation on the value attached to these resources. The people needed to be educated that apart from local advantages of ex-situ conservation through planting of economic trees and domestication of animals in meeting their social and economic needs, there are equally significant global benefits or value chains like attracting 
foreign visitors that could generate tourist dollars with the active participation of indigenous peoples. One of the global benefits is that active participation and involvement of local communities will promote development of ecotourism industry. It has been observed that development of ecotourism industry has brought the promise of achieving conservation goals, improving the well-being of local communities and generating new business, promising a rare win-win-win situation (Drumm and Moore, 2002). If ecotourism industry is embraced within the local communities, Strasdas (2002) and WTO (2002a) opined that it will have positive effect through creating job opportunities to the local people. Promotion of ecotourism therefore is considered as a way of meeting one of the needs of the local communities in provision of employment.

\section{Management approach towards conservation of Osse River Park}

Traditional approaches to park management through law enforcement have been unable to balance the competitive objectives of conserving biodiversity (Wells and Brandon, 1992). In order to engage greater percentage of the locals in the management of Osse River Park, there is need for a shift of paradigm from the present management strategy where the state government through its ministry control absolutely the management of the park. Failure of the government to constitute an independent management unit to run the affairs of the park $(13 \%)$ was rated second by the staff of NCF as part of the factors responsible for low participation and involvement of the locals in conserving the park. This approach has social and economic implications whereby local dwellers are being arrested and prosecuted for various offences like clearing and farming in the forest, while government is taking all the proceeds or revenue from the park. Thus, the locals felt cheated as they are deny of their means of livelihoods and loss of control on their naturally endowed resources. This explains the reason why change in the management approach to conservation (8\%) was part of suggestion for increase participation of local communities in conservation. Traditional paradigm has since been abolished and therefore should no longer be a practice if success is to be achieved in conserving biodiversity resources in Osse River Park. In contrast to the "traditional paradigm", in which protected areas were managed by the central government without external input, the "new paradigm" emphasizes cooperation in the governance of protected areas. Moreover, local communities should not be passive recipients of top-down guidelines, directives, and prohibitions. Rather, they should be considered as economic and cultural beneficiaries of protected areas as well as active partners. As a result, traditional management of protected areas dominated by natural scientists is gradually being replaced by socio political processes requiring consultations, sensitivity, and astute judgment (Phillips, 2003). A change in the management approach from top bottom approach to bottom top approach constitute $13 \%$ as part of suggestion by the NCF for improve participation of the locals. Rather than taking stiff measures government should create opportunity for the locals to benefit in term of employment generation and revenue earning through capacity building and training. Skidmore et al. (2006) noted that local community should not be forced, but rather be given opportunity to participate and involve in projects which affect their lives. Such an approach upheld the basic rights and a fundamental principle of democracy. Organizing the people into groups facilitate group discussions, dialogue and equal participation of the stakeholders. MacDonald and Service (2007) hold that the task of designing modern, crosscutting, transparent, evidence-based interdisciplinary decision making is not only conceptually challenging, but also necessitates a huge increase in local capacity for democracy and decision making.

According to Child (2004) by changing the question of 'who' park conservation is for from global to local, we also radically alter the question of 'what' national parks are for. The author opined that park agencies had so many demands they did not know what to focus on and at the end nothing is ever being achieved. The host communities understand themselves better, they know their plight, social and economic needs, and hence, they are in better position to plan, manage to address these through the available resources in their domain. If development of ecotourism industry is to be considered as part of the aims and objectives of establishing National Park in Nigeria, then there is need to give the locals the opportunity to plan, manage and administer the proceeds from this enterprise. Integrated Natural Resource Management approach will facilitate these opportunities. Presently it is the government of Ondo State through the state Ministry of Agriculture and Natural resources that is managing the park, thus proceeds from the park goes to the government, this idea can be regarded as 'winner takes all' .

Research studies have indicated that motivation for participation increase when the locals are involved in the management of the revenue from the park. According to Bookbinder et al. (1998), to foster greater local support for biodiversity conservation in Royal Chitwan Park, Nepal a bylaw was enacted in February 1996 decreeing that $50 \%$ of the park entry fee and a portion of concessionaires taxes must be dispensed to the local communities affected by park protection policies. The authors emphasized that prior to this provision, all park revenues was diverted from RCNP and local economy to the Ministry of Finance with only a small fraction of the 
money being reinvested into the park and no revenue was distributed to the local community. Now, there is a legal mechanism to distribute ecotourism revenue to the local village group. According to the staff of NCF, Ondo State House of Assembly should enact laws guiding the management of the park which should include among other things the sharing of the proceeds from the park in such a way that the locals will benefit from it.

\section{Forest user group(s) participation in conservation management}

Forest user groups refer to group of people in a community involve in the harvest, consumption, conservation and management of forest products like wild animals, leaves, fruits, seeds and plants of medicinal values (Richards et al., 1999; Crystal et al., 2013). Absence of this category of people as indicated by the respondents and the key informants within the communities adjoining Ose River Park calls for serious attention in the quest to achieve its sustainable biodiversity conservation and management. This has serious implication as observed by Crystal et al. (2013) and stated thus (1) It means there is lack of transparent structure whereby government and NGO regularly inform communities about forest management issues and activities, (2) It also connote that there is lack of effective communication mechanisms to promote two-way communication about forest management between communities, government and forest managers, (3) Participation management plans are not developed with involvement and participation of local communities, and (4) Communities have no adequate capacity to effectively participate in forest management planning and implementation. To address these issues raised various community forest users such as farmers, charcoal/firewood collectors and traders, hunters, timber group, honey tapper/bush meat sellers, gatherer of edible fruits/seeds and fishermen should be identified and constituted as groups no matter the size or the number of members in each group. Skidmore et al. (2006) emphasized a $1 \%$ solution as a way to reach the locals at the grass root level in order to involve them to participate in governance. Skidmore et al. (2006) opined that choosing relatively few people to participate in formal governance does not mean we should discard the ambition of community participation, but rather that we should recast it. Marten and Suutari (2006) opined that what supports communities to be involved in conservation is encouragement and inspiration, skills and knowledge, contacts and networks (for example being asked to be involved by someone they known), sufficient resources for task, opportunities for involvement, two way communication, successes and acknowledgement. The NGOs can assist in constituting these groups, monitor and evaluate the performance of each group. Child (2004) emphasized that complexity of organizing remote rural communities into common property management units could be a challenge, giving rise to fascinating experimentation and literature on governance, organizational and political theory but the gains can be immeasurable. The author opined that evidence is accumulating that community conservation management of wildlife at village level is an order of magnitude more powerful in terms of transparency, involvement, democratization, reduced corruption and misappropriation, and the number of projects built, than channeling benefits to higher-level representational committees, the want of most development projects.

\section{Capacity building and training}

Another strategy to achieve participation and involvement of host community as a stakeholder in conservation is by providing capacity building and training. NGO should be involved in capacity building so as to strengthening the abilities of the host communities of Osse River Park to be effective and efficient in the use of the biodiversity resources. Domestication of wild animal such as rearing of grasscutter/giant rat and snailry (13\%) as recorded among the respondents (Table 5) are regarded as novel biodiversity conservation practice. According to Smout et al. (2000) capacity building through skill training and confidence building can be a key ingredient in motivating and mobilizing different sections of the community to participate in the management of a project. This task rest on the NGOs in providing training for the locals in the area of alternative economic activities like domestication of wild animals like grasscutter, bee keeping and snail multiplication. Training can also be provided to improve their skill in tourism, hospitality and catering services. This is a serious challenge to all the NGOs in Ondo-State especially those that have been recognized as registered with the State Ministry of Environment or Ministry of Natural resources.

\section{Environmental education and awareness creation}

Only 20 and $10 \%$ of the respondents in the local communities identified provision of inputs and intensification of conservation education as needing attention, respectively. There is need to develop a synergy between the Government Ministries and NGO in the area of environmental conservation education and awareness creation. For instance, NCF prepared a blueprint for the development of conservation education in Ifon Forest Reserve as a way to reach the communities and educate them on the importance of biodiversity conservation (NCF, 2008). According to Nathaniel and Nathaniel (2013), it brings to some comfort to know that some 
governmental and non-governmental organizations in Nigeria in collaboration with the United Nations Environmental Programme (UNEP) and the World Wild Fund (WWF) and several other agencies have embarked on programmes to protect and preserve the nation's biodiversity.

Despite all these, the areas of participation of the locals in biodiversity conservation and the percentage of people involve in park management activities are very low. The reason is that biodiversity conservation education through the media or any form and provision of input such as seedlings for annual tree planting exercise are considered as political jamboree that have failed to address their social economic needs. Suffice to say that intensive environmental education is creating awareness among the locals but it has failed to awaken their consciousness in lending their support to biodiversity conservation and management activities, unless the socioeconomic needs of the people are met.

Despite the level of awareness being created by both the government and NGOs, there is increasing anthropogenic activities being recorded. The underline fact is that the people considered biodiversity as a mean to an end. Balmford et al. (2002) reported that biodiversity is fundamental for current, future, social and economic livelihood and human derive benefit from biodiversity have influence on ecological, cultural and social impact. According to Child (2004), the World Bank's cutting-edge literature (World Bank, 2002) advocates the theory that the best way to encourage development is to provide poor people with truly discretionary financing, the Community Based Natural Resources Management (CBNRM) movement has already experimented with cash distribution and wildlife dividends and show just how powerful fiscal devolution and discretionary financing can be. Financial empowerment will enable the communities to operate and own alternative livelihood projects, thus, heartening them to participate and involve in biodiversity conservation activities being initiated by government and NGO toward the development of Osse River Park. The implication of this is that there is need for increased financing from the present 5 to $10 \%$ NCF/NGO's input in fund raising and the government's commitment in finance from $25 \%$ (Table 9 ) to 70 to $80 \%$ or more.

\section{Preparation of management plan}

Availability of well written management plan is a necessity in the ongoing efforts at developing Osse River Park. Management plan is a very comprehensive document; it can be regarded as a blue print containing information on the aims and objectives of conserving the park, inventory of fauna, flora and cultural resources in the park, social, economic and demographic information of the adjoining communities. The management plan also contain information on the land use practice and human settlement, the management problems and challenges, boundary demarcation, road development, culture and tradition, and alternative economic activities to sustain the locals in the course of conservation, etc (Afolayan et al., 1997). This blue print is an aftermath of a comprehensive research undertaken over a period of 2 to 3 years through integrated and consortium approach. Experts are drawn from various fields of natural resources management, biodiversity conservation, community development, sociology, ecology, economists, environmentalists', etc. Lack of management plan as noted in this research work, therefore raises so many questions and this might create imbalance in the integration process. The resultant effect is total disintegration, lack of support and cooperation among the stakeholders. Osse River Park is in transition period from forest reserve of many years to a park. This might generate confusion and conflict among the locals and other stakeholders unless a management plan is prepared where the roles of all the stakeholders are clearly spell out. For instance, while forest reserve permits the local communities to harvest and collect forest and non-forest products for their subsistence, such activities are strictly prohibited in the park. According to FAO (2003), forest reservation was usually done in consonance with the local communities, who were authorized to continue their former uses of the forests, so far as such practices did not contravene the management of the forest for timber production. In contrary, park is a protected area managed for ecosystem conservation and recreation, they fall under Category II of protected area with clear boundaries drawn sufficiently to contain one or more entire ecosystem which are not subject to material modification by human exploitation or occupation (IUCN/WCMC, 1994). The imbalance between the stakeholders can be addressed by preparing a management plan thereby facilitating cooperation, mutual understanding and participation among the stakeholders in the integration process.

\section{Conclusion}

Despite financial and materials input of both the government and NGO environmental education and conservation of Osse River Park, the level of participation and involvement of the host communities in conservation and management of the park were observed to be very low. Increasing efforts are needed in the area of capacity building and training, employment and providing alternative economic activities to the support zone communities. The need for a change of paradigm in the management of the park was also emphasized. All these can be achieved through participatory approach in natural 
resources management. This approach will facilitate cooperation, support, involvement and participation among the stakeholders. Also, government and NGOs should increase their financial contribution and capacity building respectively towards the park and its host communities. Finally, the development of ecotourism practices as part of integration process will go a long way in addressing some of the imbalance observed in this research work.

\section{CONFLICT OF INTERESTS}

The authors have not declared any conflict of interests.

\section{REFERENCES}

Adeyemo Al, Oladeji SO (2013). Ecotourism for stemming employment, terrorism and alleviating poverty in West Africa: Proceedings of $3^{\text {rd }}$ Regional Conference on Tourism Research 29th-31st, Oct., 2013, Langkawi, Malaysia, pp. 199-205

Afolayan TA, Agbelusi EA, Ayodele IA, Balogun AM, Soladoye MO, Agbaje-Williams B, Fasakin EA, Ogunmodede MS (1997). Management Plan of Old Oyo National Park pp. 215-237.

Agbelusi EA, Afolayan TA (1991). Mammalian specie of Ifon Game Reserve. J. Environ.Conserv.19(1):74-76.

Balmford A, Bruner A, Cooper P, Costanza R, Farber S, Green RE, Jenkins M, Jefferiss $P$, Jessamy V, Madden J, Munro K, Myers N, Naeem S, Paavola J, Rayment M, Rosendo S, Roughgarden J, Trumper K, Turner RK (2002). Economic reasons for conserving wild nature. Science 297(5583):950-953.

Bamgboye EA, Okoruwa VO (2009). Designs of Experiments and Surveys. In Data collection, Management and Analysis in Academic Research, Proceedings of a Workshop, Ed.L. Popoola, O. Olorunnisola and O. Ademowo

Bookbinder M, Dinerstein E, Rijal A, Cauley H, Rajouria A (1998). Ecotourism's support of biodiversity conservation. Conserv. Biol. 12(6):1399-1404.

Child B (2004). Parks in transition. Biodiversity, Rural Development and Bottom Line. Earthscan in the UK and USA in 2004.

Crystal D, Lauren W, Sarah L, Florence D (2013). Assessing forest governance. The governance of forests Initiative Indicator. World Resource Institute

Daily GC (1997). Nature's Services: Societal Dependence on Natural Ecosystems. Island Press: Washington, D.C.

Dohrmann S, Diafeng H, Leyla M (2006). Residential Address Lists vs. Traditional Listing: Enumerating Households and Group Quarters. In JSM Proceedings, Survey Research Methods Section, 2959-2964. Alexandria, VA: American Statistical Association.

Drumm A, Moore A (2002). Ecotourism Development: A Manual for Conservation Planners and Managers. Arlington, VA: The Nature Conservancy.

European Union (EU) (2015). Factsheet on the new framework for Gender Equality and Women's Empowerment: Transforming the Lives of Girls and Women through EU External Relations (20162020), Brussels, 22 September 2015.

Dudley N (2008). IUCN Guidelines for Applying Protected Area Management Categories.

Epler W (2002). Ecotourism: Principles, Practices and policies for Sustainability, UNEP, Division of Technology, Industry and Economics.

Food and Agricultural Organisation FAO (2003). Experience of Implementing National Forest programmes in Nigeria. Sustainable Forest Management Programmes in African ACP Countries. EC-FAO PARTNERSHIP PROGRAMME (2000-2003) EC Tropical Forestry
Budget Line Project B7-6201/98-08/VIII/FORProject GCP/RAF/354/EC

Food and Agricultural Organisation FAO (2013). Advancing agroforestry on the policy agenda: Guide for decision makers.

FRNOG. (2009). Legal notice on publication of 2006 census final results. Federal Republic of Nigeria Official Gazette, 96:B1-42.

ICOMOS (1993). Guidelines for Education and training in the conservation of Monuments, Ensembles and Sites (1993) https://www.scribd.com/document/284543599/lcomos-1993Guidelines-Education

International Union for Conservation of Nature and Natural Resources IUCN/WCMC, (1994). Guidelines for Protected Area Management Categories. Gland and Cambridge: IUCN.

Johnson CJ, Boyce MS, Case RL, Cliff HD, Gau RJ, Gunn A, Mulders R (2005). Cumulative effects of human developments on arctic wildlife. Wildl. Monogr. 160.

Kabwe G, Bigsby H, Cullen R (2009). Factors influencing adoption of agroforestry among smallholder farmers in Zambia. Paper presented at the 2009 NZARES Conference Tahuna Conference Centre Nelson, New Zealand. August 27-28, 2009.

Kennel TL, Liu X (2011). Is Housing Unit Undercoverage random? In JSM proceedings Survey Research Methods Section 3697-3707 Alexandria, VA: American Statistical Association.

MacDonald D, Service K (2007). Key Topics in Conservation Biology. Blackwell Publications, Oxford.

Marten G, Suutari A (2006). Reversing Tropical Deforestation: Agroforestry and Community Forest Management (Nakhon Sawan Province, Thailand). Posted July, 2006.

Nathaniel IT, Nathaniel A (2013). The effects of poverty in conservation of biodiversity: The Nigeria Experience. Science in Africa.

National Environmental Awareness Campaign NEAC, (2012). Biodiversity Conservation. Cited 2013. Available from: http://moef.nic.in/sites/default/files/NEAC\%20201213\%20background\%20paper\%20FN.pdf

Nigeria Conservation Foundation NCF, (2007). Biodiversity survey of Ifon Forest Reserve, Ondo State, Nigeria.

Nigeria Conservation Foundation NCF, (2008). Blueprint for the development of conservation Education in Ifon Forest Reserve,Ondo State, Nigeria. Technical presentation, 86pp.

Oladeji SO, Afolayan TA (2009). Contributions of Environmental NGOs in information dissemination aimed at combating Climate change. In : Ed . Isiche A . Theme: Your planet needs you Unite to Combat Climate Change. Proceedings of the 2nd Annual Conference of Institute of Technology and Environmental Studies Obafemi Awolowo University (OAU). 9th-11th of June 2009.

Oladeji SO, Agbelusi EA, Trevelyan R (2012). Anthropogenic activities threatening the Management of the Ecotourism resources in Old Oyo National Park, Nigeria. Ethop. J. Environ. Stud. Manag. 5(1):110-111.

Oladeji SO, Kayode O (2013). Ecotourism Industry a panacea for Sustainable economic Development in rural communities: case study of Osse River Park, Ondo-State, Nigeria. J. Sustain. Dev. Afr. 18(8):2-93

Oladeji SO (2015). Community based ecotourism management practice a panacea for sustainable rural development in Liberia. J. Res. For. Wildl. Environ. 7(1):136-153.

Phillips A (2002). Management Guidelines for IUCN Category V Protected Areas. Protected Landscape/Seascape. Best practice protected area guidelines series No.9.

Phillips A (2003). Management Guidelines for IUCN Category V Protected Areas. Protected Landscape/Seascape. Best practice protected area guidelines series No.9.

Richards M, Kanel K, Maharjan M, Davies J (1999). Towards participatory economic analysis by forest user groups in Nepal. Overseas Development Institute in collaboration with the Nepal-UK Community Forestry Project. Financed by the Forestry Research Programme of the UK Department for International Development (DFID).

Rosario EA (1997). The conservation management plan of the protected araes other than those in Sundarbarban in Bangladesh, Forest Resource Management Project, Bangladesh Forest 
Department, Ministry of Environment and Forsts: Dhaka.

Royal Society (2003). Measuring Biodiversity for Conservation, Document $11 / 03$.

Sakai S (2003): Participatory Environmental Management Approach: Sabah Parks Staff Training Participatory Park Management and Social Study 12 March, 2003 (Wed) Main Text, Pp. 1- 6.

Sarantakos S (1988).Social Research (2nded.). Palgrave Publisher Ltd (Formerly Macmillan Press Ltd), Charles Stuart University, Australia. pp. $139-141,144-145,148$

Sharma R, DeCosse P, Khan M, Mazmumder A (2005). CoManagement of Protected Areas in South Asia with special reference to Bangladesh. Nishorgo Support Project. Dhaka.

Sharma UR, Yonzon PB (2005). People and Protected Areas in South Asia. IUCN and Resources Himalaya Foundation. Nepal

Simpson K (2001). Strategic planning and community involvement as contributors to sustainable tourism development. Curr. Issues Tour. 4(1):3-41.

Skidmore P, Bound K, Lownsbrough H (2006). Community participation. Who benefits. Joseph Rowntree Foundation. [cited 2013 Oct.,30].

Smout I, Samson K, Coates S, Snel M (2000). Community and Management. A postgraduate distance learning module, WEDC, Loughborough University.

Spenceley A (2003). Tourism, local livelihoods and the private sector in South Africa: case studies on the growing role of the private sector in the natural resources management. Sustainable Livelihoods in Southern Africa Research Paper 8, Institute of Development Studies, Brighton http://www.ids.ac.uk/slsa

Spears J, Oram P, Byron N, Scherr S, Izac M (1994). A Review of Tropical Forestry and Agroforestry Problem Areas and Policy Research Needs and the Planned Response of the CGIAR System.CIFOR Working Paper no. 5.

Stewart S (2004). The role of International and Local NGOs in the Transformation of the Georgian-Abkhazian Conflict. Global Rev. Ethnopolitics 3(3-4).3-22.

Strasdas W (2002). Ecotourism Training Manual for Protected Area Managers .German Foundation for International Development (DSE) Center For Food, Rural Development and The Environment (ZEL) Feldafing And Zschortatu, Germany.
Swarthout E, Steidl RJ (2001). Flush responses of Mexican spotted owls to recreationists. J. Wildl. Manag. 65:312-317.

United Nations Conference on Environment and Development UNED, (1992). Canada's National Report. Brazil, June 1992.

Wells M, Brandon K (1992). People and Parks: Linking Protected Area Management with Local Communities. Washington, D.C.: World Bank, World Wildlife Fund (WWF) and U.S. Agency for International Development (USAID).

World Bank (2002). Linking Poverty Reduction and Environmental Management: Policy Challenges and Opportunities. The World Bank Washington, DC.

WTO (2002a). Tourism proves to be a resilient and stable economic sectors (18, June) available at http.www.world tourism.org.newsroom. Release more release June 2002.data.htm 